\title{
Pengaruh Pemberian Level Protein Pakan Berbeda terhadap Performa Ayam Merawang Umur 2-12 Minggu
}

Rekno Dewati, Hidayat, Kususiyah*

Jurusan Peternakan, Fakultas Pertanian, Universitas Bengkulu

Jalan W. R Supratman, Kandang Limun, Bengkulu, 38371 A

*Korespondensi: kususiyah@unib.ac.id

Artikel ini diterima (received): 22 November 2019; dinyatakan disetujui (accepted): 15 Januari 2020; terbit (published): 15 Mei 2020. Artikel ini dipublikasi secara daring pada https://ejournal.unib.ac.id/index.php/buletin_pt

\section{ABSTRAK}

Penelitian ini menggunakan Rancangan Acak Lengkap (RAL) dengan 3 perlakuan level protein yaitu : $\mathrm{P} 1=17 \%, \mathrm{P} 2=18 \%$, dan $\mathrm{P} 3=19 \%$ dengan 10 ulangan, dan setiap ulangan menggunakan 2 ekor ayam umur 2 minggu (14 hari). Hasil penelitian menunjukkan bahwa perbedaan level protein pakan berpengaruh tidak nyata $(P>0,05)$ terhadap konsumsi pakan kumulatif (umur 2 -12 minggu), sedangkan berat badan, pertambahan berat badan dan konversi pakan berpengaruh nyata $(P<0,05)$. Berdasarkan data konsumsi pakan, berat badan, dan konversi pakan, dapat disimpulkan bahwa pemberian pakan ayam Merawang umur 2 - 12 pada level protein pakan 18\% merupakan level protein pakan yang optimal.

Kata kunci: Ayam Merawang, protein, performa

\section{PENDAHULUAN}

Meningkatnya kesadaran masyarakat akan pentingnya mengkonsumsi protein hewani berpengaruh terhadap tingginya permintaan konsumen terhadap telur ayam. Telur ayam yang merupakan produk utama dari sektor usaha ayam petelur, adalah bahan pangan yang memiliki nilai gizi tinggi dan mudah tercerna oleh tubuh serta memiliki harga yang cukup terjangkau oleh semua kalangan masyarakat Indonesia. Dewasa ini permintaan konsumen akan telur ayam kampung maupun ayam Ras mulai meningkat. Ayam kampung merupakan ayam asli Indonesia yang sudah banyak dikenal oleh masyarakat dengan sebutan ayam buras (bukan ras), atau ayam sayur. Kelebihan ayam kampung ini merupakan tipe ayam dwiguna yang dapat dimanfaatkan sebagai produksi telur dan daging. Kelemahan dari ayam ini adanya aktivitas mengeram dan mengasuh anak yang lama serta produksi telur yang rendah sekitar 39-130 butir/ekor/tahun (Sartika, 2005). Ayam kampung yang merupakan ayam asli Indonesia terdiri dari beberapa jenis yaitu ayam Kedu Hitam, ayam Kedu Putih, ayam Kedu Merah, ayam Kedu Cemani, ayam Nunukan, ayam
Pelung, ayam Sentul, ayam Banten, ayam Gaok, ayam Ciparage, ayam Bali, ayam Wareng, ayam Ayunai, ayam Tolaki, ayam Delona dan ayam Merawang (Astuti, 2010).

Ayam Merawang merupakan ayam kampung yang berasal dari Bangka Belitung. Nama tersebut didasarkan pada penyebaran dari ayam ini yang terkonsentrasi di Desa Merawang di daerah Sumatera bagian selatan khususnya di Pulau Bangka. Bobot badan ayam Merawang dewasa adalah 1,5 kg dan bertelur pertama pada umur 5,5 bulan dengan produksi telur dapat mencapai 125 butir/ekor/tahun (BPTU-HPT Sembawa, 2001). Sampai saat ini informasi ayam Merawang di Bengkulu belum banyak diketahui, sehingga perlu dilakukan evaluasi kandungan level protein pakan yang berbeda terhadap performa ayam merawang fase starter.

Periode starter adalah fase kritis pemeliharaan ayam petelur dimana keberhasilan untuk menciptakan kondisi yang optimal bagi tumbuh kembang anak ayam hingga pullet menjadi modal dasar suksesnya peternakan ayam petelur. Pembelahan dan pertumbuhan sel yang tinggi terjadi pada periode starter sehingga periode ini merupakan 
kunci awal untuk mencapai keberhasilan pencapaian bobot badan. Menurut Pambudhi (2003) dikutip oleh Diana (2012) yaitu umur 1 12 minggu. Fase starter sangat penting, karena fase ini sangat berpengaruh terhadap masa produksi, jika terjadi kesalahan dalam pemeliharaan fase starter maka ayam pada masa produksi akan mengalami gangguan seperti kelumpuhan dan produktifitas yang rendah.

Pakan merupakan komponen penting dalam usaha pengembangan ayam Merawanag fase starter, karena untuk menghasilkan performa sesuai yang diinginkan tergantung dari kualitas pakan yang diberikan, kandungan nutrisi pakan seperti protein, energi dan lain lain. Pakan yang baik adalah pakan yang mengandung gizi sesuai dengan kebutuhan ternak unggas menurut jenis, bangsa dan umur unggas. Disamping itu pakan yang baik juga tidak berjamur, tidak basi maupun berbau tengik dan tidak terdapat benda - benda asing yang tidak bermanfaat bagi unggas dan dapat mengganggu pencernaan.

Protein merupakan nutrisi yang sangat berperan penting pada pertumbuhan ayam diantaranya untuk pertumbuhan tulang, daging, kulit, bulu serta berperan penting untuk mengganti jaringan yang rusak sehingga ketersediaan protein dalam ransum perlu diperhatikan, sementara itu bahan pakan yang mengandung protein merupakan bahan pakan yang mahal. Oleh karena itu, level protein perlu menjadi perhatian dalam menyusun ransum.

Berdasarkan uraian diatas penulis tertarik untuk melakukan penelitian mengenai pengaruh pemberian level protein ransum berbeda terhadap performans ayam Merawang fase starter. Diduga pemberian level protein pakan yang berbeda diduga berpengaruh terhadap perfoma ayam Merawang umur 2 12 minggu.

\section{MATERI DAN METODE}

\section{Persiapan kandang}

Kandang yang digunakan adalah kandang batteray berukuran panjang $30 \mathrm{~cm}$, lebar $40 \mathrm{~cm}$ dan tinggi $22 \mathrm{~cm}$ sebanyak 30 unit. Kandang dilengkapi dengan tempat pakan dan minum, lampu pijar 40 watt yang berfungsi sebagai penerang.

Persiapan kandang sebelum penelitian adalah renovasi kandang, sanitasi kandang, pembersihan kandang dari semua kotoran, sterilisasi kandang, memasang lampu listrik, membersihkan tempat pakan dan minum serta semua peralatan di semprot dengan desinfektan. Kandang diberi label setelah dilakukan pengacakan dari masing-masing perlakuan dan ulangan. Setiap unit kandang terdiri dari 2 ekor ayam.

\section{Pemeliharaan ayam perlakuan}

Penelitian ini menggunakan Rancangan Acak Lengkap (RAL) dengan 3 perlakuan level protein yaitu : $\mathrm{P} 1=17 \%, \mathrm{P} 2=18 \%$, dan $\mathrm{P} 3=19 \%$ dengan 10 ulangan. Setiap ulangan menggunakan 2 ekor ayam umur 2 minggu (14 hari), sehingga masing-masing perlakuan dibutuhkan 20 ekor ayam yang ditempatkan secara acak pada kandang bateray.

Ayam Merawang yang berumur 2 minggu dipilih secara acak kemudian dimasukkan ke dalam kandang batteray untuk perlakuan. Perlakuan terdiri dari 10 ulangan dimana dalam setiap ulangan terdapat 2 ekor ayam.

Pakan yang diberikan merupakan pakan formulasi yang terdiri dari KLK dan jagung giling. Pemberian pakan dilakukan 2 kali sehari yaitu pada pukul 07.00 pagi dan 16.00 sore. Tempat air minum dibersihkan setiap akan dilakukan pergantian air minum. Jumlah pemberian pakan mengacu pada ransum ayam petelur coklat (Amrullah, 2003) dapat dilihat pada Tabel 1. Formulasi pakan perlakuan dan kandungan nutrisi pakan penelitian dicantumkan pada Tabel 2. Variabel yang diamati meliputi konsumsi pakan, berat badan, pertambahan berat badan dan konversi pakan.

\section{Analisis data}

Data yang diperoleh dianalisis dengan menggunakan ANOVA dan jika terdapat pengaruh yang nyata $(P<0,05)$ maka diuji lanjut dengan Duncan's Multiple Range Test (DMRT) untuk melihat perbedaan antar perlakuan (Steel and Torrie, 1980).

\section{HASIL DAN PEMBAHASAN \\ Konsumsi pakan}

Rataan konsumsi pakan kumulatif ayam Merawang yang dipelihara mulai umur 2 sampai 12 minggu disajikan pada Tabel 3. Hasil analisis ragam menunjukkan bahwa level protein pakan berpengaruh tidak nyata $(P>0,05)$ terhadap konsumsi pakan kumulatif sampai umur 6 minggu dan berpengaruh nyata pada umur ke 7 hingga 10 minggu, kemudiam 
kembali berpengaruh tidak nyata pada minggu ke 11 dan 12. Hasil uji lanjut konsumsi pakan kumulatif umur 7 sampai 10 minggu menunjukkan bahwa konsumsi P3 berbeda tidak nyata dengan $\mathrm{P} 2$ namun nyata lebih tinggi dibanding P1. Hal ini menunjukkan bahwa konsumsi pakan P1 dengan level protein terendah (17\%) adalah lebih tinggi dibanding dengan konsumsi pakan $\mathrm{P} 2$ dengan protein $18 \%$ dan P3 19\% sebagai bentuk kompensasi pencukupan asupan protein. Selanjutnya, meskipun berpengaruh tidak nyata konsumsi pakan kumulatif umur 11 dan 12 minggu cenderung lebih rendah dengan meningkatnya protein pakan. Konsumsi pakan kumulatif pada umur 12 minggu yaitu P1 $(2832,45 \mathrm{~g})$, P2 $(2763,80 \mathrm{~g})$ dan P3 $(2758,80 \mathrm{~g})$. Terjadinya kecenderungan penurunan konsumsi pakan kumulatif 12 minggu dengan meningkatnya level protein karena semakin tinggi kandungan protein pakan diduga protein yang dikonsumsi sudah dapat mencukupi kebutuhan ayam Merawang. Hal ini sesuai dengan pendapat Amrullah (2003) menyatakan besarnya konsumsi pakan tergantung kandungan protein pada pakan. Konsumsi pakan pada setiap perlakuan meningkat dengan bertambahnya umur ayam. Hal ini sesuai dengan pendapat Fajri (2012) bahwa selain memperhatikan kualitas pemberian pakan, pemberian pakan juga harus sesuai dengan umur ayam karena nilai gizi dan jumlah pakan yang diperlukan pada setiap pertumbuhan berbeda.

\section{Berat badan}

Rataan berat badan ayam Merawang mingguan yang dipelihara mulai umur 2 sampai 12 minggu disajikan pada Tabel 4.
Hasil analisis ragam menunjukkan bahwa level protein ransum berpengaruh tidak nyata $(\mathrm{PO}>0,05)$ terhadap berat badan mingguan ayam Merawang umur minggu ke 3 sampai 11 minggu, kemudian berpengaruh nyata pada berat badan umur ke 12 minggu. Hasil uji lanjut menunjukkan bahwa capaian berat badan ayam Merawang pada umur 12 minggu, P1 $(592,45 \mathrm{~g})$ nyata lebih rendah dibandingkan dengan P3 $(619,10 \mathrm{~g})$ tetapi berbeda tidak nyata dengan P2 $(646,95 \mathrm{~g})$ sedangkan berat badan P2 berbeda tidak nyata dengan P3. Hal ini menunjukkan bahwa berat badan ayam Merawang meningkat seiring dengan meningkatnya level protein dalam pakan. Lebih tingginya capaian berat badan pada umur 12 minggu pada P3 dengan protein yang lebih tinggi disebabkan karena intake protein. P3 $(524,17 \mathrm{~g})$ lebih tinggi dibanding intake protein P2 $(497,48 \mathrm{~g})$ dan P1 $(481,52 \mathrm{~g})$. Menurut Andhikasari, et al. (2014) protein merupakan unsur penting yang diperlukan untuk pertumbuhan dan efisiensi pakan dalam unggas. Secara umum, protein ransum unggas dipenuhi dari protein hewani (tepung ikan) dan protein nabati (bungkil kedelai) yang harganya cukup mahal.

Tabel 1. Jumlah pemberian pakan

\begin{tabular}{cc}
\hline $\begin{array}{c}\text { Umur } \\
\text { (Minggu })\end{array}$ & $\begin{array}{c}\text { Konsumsi } \\
\text { Pakan }(\mathrm{g} / \text { minggu })\end{array}$ \\
\hline Awal & 50 \\
2 & 140 \\
4 & 260 \\
6 & 340 \\
8 & 360 \\
10 & 380 \\
12 & 400 \\
\hline
\end{tabular}

Tabel 2. Formulasi Pakan Perlakuan Umur 2-12 Minggu

\begin{tabular}{lccc}
\hline Kandungan Pakan & P1 & P2 & P3 \\
\hline Dedak (\%) & 42 & 35 & 23 \\
Jagung giling ( halus ) (\%) & 28 & 30 & 37 \\
KLK (\%) & 30 & 35 & 40 \\
Total & 100 & 100 & 100 \\
\hline PK (\%) & 17,01 & 18,07 & 19,02 \\
EM (Kkal/kg) & 2773,08 & 2802,3 & 2874,57 \\
Ca (\%) & 3,30 & 3,85 & 4,40 \\
P (\%) & 0,99 & 0,97 & 0,89 \\
SK (\%) & 7,84 & 7,4 & 6,48 \\
\hline
\end{tabular}


Tabel 3. Konsumsi pakan kumulatif ayam Merawang

\begin{tabular}{|c|c|c|c|c|c|}
\hline \multirow{2}{*}{$\begin{array}{l}\text { Konsumsi } \\
\text { kumulatif } \\
\text { (minggu) }\end{array}$} & \multicolumn{3}{|c|}{ Perlakuan } & \multirow[t]{2}{*}{ Ket } & \multirow[t]{2}{*}{$P$} \\
\hline & $\mathrm{P} 1(17 \%)$ & $\mathrm{P} 2(18 \%)$ & P3(19\%) & & \\
\hline \multicolumn{6}{|c|}{ - } \\
\hline 3 & $134,00 \pm 22,00$ & $115,30 \pm 18,19$ & $130,15 \pm 8,54$ & ns & 0,52 \\
\hline 4 & $285,10 \pm 36,57$ & $260,75 \pm 31,54$ & $277,35 \pm 9,66$ & ns & 0,16 \\
\hline 5 & $471,05 \pm 41,95$ & $432,75 \pm 40,63$ & $463,90 \pm 30,47$ & ns & 0,07 \\
\hline 6 & $703,00 \pm 56,24$ & $656,40 \pm 47,82$ & $674,85 \pm 44,89$ & $\mathrm{~ns}$ & 0,12 \\
\hline 7 & $1009,85 \pm 70,40^{\mathrm{a}}$ & $940,30 \pm 52,84^{b}$ & $942,80 \pm 59,65^{b}$ & $*$ & 0,02 \\
\hline 8 & $1354,20 \pm 77,12^{\mathrm{a}}$ & $1281,35 \pm 60,46^{b}$ & $1277,25 \pm 65,44^{b}$ & $*$ & 0,04 \\
\hline 9 & $1703,35 \pm 80,68 a$ & $1631,35 \pm 61,13^{b}$ & $1626,10 \pm 69,70^{b}$ & $*$ & 0,03 \\
\hline 10 & $2070,50 \pm 83,25^{a}$ & $1998,50 \pm 64,74^{b}$ & $1993,70 \pm 70,71^{b}$ & $*$ & 0,04 \\
\hline 11 & $2446,95 \pm 85,12$ & $2375,70 \pm 68,55$ & $2370,95 \pm 74,26$ & ns & 0,06 \\
\hline 12 & $2832,45 \pm 87,59$ & $2763,80 \pm 68,91$ & $2758,80 \pm 77,27$ & ns & 0,07 \\
\hline
\end{tabular}

Keterangan : Superskrip berbeda pada baris yang sama menunjukkan berbeda nyata $(P<0,05)$

Dewanti (2009) menyatakan semakin bertambahnya umur ternak maka akan mengalami pertambahan berat badan termasuk perubahan komponen - komponen tubuh seperti otot, tulang, lemak dan protein. Protein merupakan nutrisi makana yang sangat berperan dalam fase pertumbuhan.

\section{Konversi pakan}

Konversi pakan kumulatif ayam Merawang yang dipelihara mulai umur 2 sampai 12 minggu disajikan pada Tabel 5.

Hasil analisis ragam menunjukkan bahwa level protein pakan berpengaruh tidak nyata terhadap konversi pakan kumulatif ayam Merawang umur ke 3 sampai dengan 9 minggu, tetapi berpengaruh nyata terhadap umur 10 sampai 12 minggu. Hal ini menunjukkan bahwa pada awalnya (selama umur 2 - 9 minggu) perbedaan level protein tidak berpengaruh terhadap koversi pakan, namun setelah umur 9 minggu, perbedaan level protein berpengaruh terhadap konversi pakan, ini diduga karena pada umur 11 sampai dengan 12 minggu level protein berpengaruh pada pertambahan berat badan ayam Merawang. Hasil uji lanjut menunjukkan bahwa konversi pakan kumulatif ayam Merawang $\mathrm{P} 1(4,92)$ umur 10 berbeda tidak nyata dengan $\mathrm{P} 2(4,80)$ tetapi nyata lebih tinggi dibanding $P 3(4,51)$. Hasil uji lanjut konversi kumulatif $\mathrm{P} 1(5,22)$ umur 11 minggu nyata lebih tinggi dibanding dengan $\mathrm{P} 2(5,03)$ dan P3(4,65). Uji lanjut konversi pakan kumulatif umur 12 minggu menunjukkan bahwa P1 $(5,40)$ nyata lebih tinggi dibandingkan dengan P2 $(5,00)$ dan P3 $(4,76)$. Berdasarkan konversi pakan kumulatif umur 12 minggu dapat diketahui bahwa konversi pakan ayam Merawang dengan protein 18\% dan 19\% nyata lebih rendah dibanding level protein $17 \%$. Hal ini menunjukkan bahwa level protein pakan ayam Merawang dengan protein $17 \%$ (P1) adalah paling tidak efisien dibanding level protein $18 \%$ (P2) dan 19\% (P3). Pakan dengan level protein $17 \%$ adalah pakan yang mengandung serat kasar paling tinggi, yaitu $7,84 \%$ dibanding P2 dengan serat kasar 7,4\% dan $\mathrm{P} 3$ dengan kandungan serat kasar $6,48 \%$. Anggorodi (1985) menyatakan bahwa pemberian serat kasar diatas $7 \%$ dalam ransum akan menyebabkan hambatan pertumbuhan karena intake protein rendah sehingga mengakibatkan gizi hilang bersama keluarnya eksreta dan efisiensi penggunaan pakan tetap. Konsumsi pakan dan pertambahan bobot badan akan mempengaruhi konversi pakan.

\section{KESIMPULAN}

Berdasarkan data konsumsi pakan, berat badan, dan konversi pakan, dapat disimpulkan bahwa pemberian pakan ayam Merawang umur 2-12 minggu level protein pakan 18\% merupakan level protein pakan yang optimal dibandingkan dengan level protein $17 \%$ dan level protein $19 \%$. 


\section{DAFTAR PUSTAKA}

Amrullah, I. K. 2003. Nutrisi Ayam Petelur. Lembaga Satu Gunung Budi. Bogor

Andikasari, K. 2012. Efisiensi penggunaan protein pada ayam Broiler dengan pemberian pakan mengandung tepung daun kayambang (Salvinia molesta). Tesis. Program Studi Magister Ilmu Ternak Fakultas Peternakan dan Pertanian Universitas Diponegoro, Semarang.

Anggorodi, R. 1985. Kemajuan Mutakhir dalam IImu Makanan Ternak Unggas. UI-Press. Bogor.

Astuti, J. M., H. Mulyadi dan J. H. P. Sidadolog. 1980. Pengukuran Parameter Genetik Ayam Lokal. Fakultas Peternakan. Universitas Gadjah Mada, Yogyakarta

BPT-HMT Sembawa. 2001. Budidaya Ayam Buras. BPT-HMT Sembawa, Palembang.

Dewanti, R., J. H. P. Sidadolog dan Zuprizal. 2009. Pengaruh pejantan dan pakan terhadap pertumbuhan itik Turi sampai umur delapan minggu. Buletin Peternakan, 33 (2): 88-95.

Diana. 2012. Performans ayam Arab (Gallus turcicus) periode starter yang diberi ransum dengan level protein dan energi yang berbeda. Skripsi. Program Studi Peternakan Fakultas Pertanian dan Peternakan Universitas Islam Negeri Sultan Syarif Kasim. Pekanbaru. Riau.

Fajri, N. 2012. Pertambahan berat badan, konsumsi dan konversi pakan broiler yang mendapat ransum mengandung berbagai level tepung daun katuk (Sauropus androgynus). Skripsi. Fakultas Peternakan. Universitas Hasanudin Makasar. Makasar.

Sartika. T. 2005. Peningkatan mutu bibit ayam kampung melalui seleksi dan pengkajian penggunaan penanda genetik promotor prolaktin dalam MAS/Marker Assiated Selection untuk mempercepat proses seleksi. Disertasi. Sekolah Pascasarjana Institut Pertanian Bogor.

Steel, R. G. D. and J. H Torrie. 1980. Principle and Procedures of Statistics. Diterjemahkan oleh Sumantri, B. 1993. Prinsip dan Prosedur Statistika "Suatu Pendekatan Biometrik". PT. Gramedia Pustaka Utama, Jakarta 